\title{
Digital inclusion in education in Tarija, Plurinational State of Bolivia
}

\author{
Sulma Farfán Sossa, Antonio Medina Rivilla \\ and María Luz Cacheiro González
}

ABSTRACT

This study analyses digital inclusion in secondary education in the Tarija School District in the Plurinational State of Bolivia for the 2012-2013 school year, using the indicators in the Plan of Action for the Information Society in Latin America and the Caribbean (Plan of Action eLAC). This is an exploratory and descriptive analysis based on a sample of 311 students, 108 teachers and 15 school principals. According to the findings, teenagers use the Internet to look for information and entertainment; the expansion of mobile technology among them offers numerous educational opportunities; and insufficient training for teachers on how to integrate information and communications technologies (ICTS) into the learning process is a top challenge. The existence of ICTS in schools has been confirmed, but not their use. Local and national efforts are helping to reduce the digital divide and promote equality of opportunity for young people. technology, communication technology, programmes of action, equal opportunity, ICT indicators, Bolivia (Plurinational State of) sfarfan@slu.edu

Antonio Medina Rivilla is a professor at the National Distance Education University (UNED), Spain. amedina@edu.uned.es

María Luz Cacheiro González is a professor at the National Distance Education University (UNED), Spain. mlcacheiro@edu.uned.es 


\section{I}

\section{Introduction}

Information and communications technologies (ICTS) are a necessary tool of daily life. Their advantages make them strategic resources for the development of new knowledgebased economies.

Since the World Summit on the Information Society (WsIs, 2003), ICT access, availability and use have become key issues in the social and economic development of societies. This new reality has required governments to implement policies and programmes that guarantee the integration of ICTs into the information and knowledge society. One of the basic ways of achieving this integration is through the education system, which is responsible for training new generations in the skills that are indispensable for the information society.

Although ICTs are increasingly available, there are significant disparities between developed and developing countries, giving rise to a major gap in access known as the "digital divide".

To overcome ICT-based inequalities, digital inclusion plans that go beyond simple technological equipment are being implemented in various countries (UNESCO, 2013a; Eurydice, 2011). In the case of the Plurinational State of Bolivia, some initial steps to develop ICT policies were taken in 2002 but it was only in 2005 that these policies were deployed in the educational system, paving the way for various initiatives to reduce the digital divide.

This study draws on a number of proposed indicators of ICT in education to help determine the state of digital inclusion, and the indicators proposed in the Plan of Action for the Information Society in Latin America and the Caribbean (Plan of Action elAC) (ECLAC, 2012a) are used to analyse data collected on the Tarija School District. In addition, studies conducted in other departments in the Plurinational State of Bolivia and neighboring countries have been considered.

The article is structured as follows. Section II addresses the challenges raised by the socalled information society. Section III discusses the digital divide and inclusion, as well as the major inequalities in access to ICTs. Section IV points up the need to use indicators of the levels of digital inclusion in education. Section V covers the implementation of ICTs in education, and section VI examines digital inclusion in the Plurinational State of Bolivia. Sections VII and VIII provide context and present the methodology used to conduct the research, and section IX discusses characteristics of the sample. Section X and XI analyse the findings based on the indicators, as well as other studies. Lastly, section XII offers the study conclusions.

\section{II}

\section{Challenges of the information society}

The World Summits on the Information Society at Geneva (wsIs, 2003) and at Tunis (wsIs, 2005) produced an explicit declaration of the political will of the participating countries "to build an inclusive Information Society; to put the potential of knowledge and ICTs at the service of development; to promote the use of information and knowledge for the achievement of internationally agreed development goals, including those contained in the Millennium Declaration [...]" (wsIs, 2003, p. 2). The declaration emphasized the need to incorporate ICTs in education as a strategic element for a digitally inclusive society. A first step in this task is to eradicate basic illiteracy and "develop domestic policies to ensure that
ICTS are fully integrated in education and training at all levels, including in curriculum development, teacher training, institutional administration and management, and in support of the concept of lifelong learning" (wsis, 2003 , p. 6), as well as "ensure that young people are equipped with knowledge and skills to use ICTs, including the capacity to analyse and treat information in creative and innovative ways, share their expertise and participate fully in the Information Society" (wsis, 2003, p. 6).

The World Summit on the Information Society and the Millennium Development Goals (MDGs) are the basis for the Plan of Action elaC being promoted by the Economic Commission for Latin America and the Caribbean 
(ECLAC). The plan is a political agenda agreed upon by the countries in the region that views ICTS as instruments for economic development and social inclusion.

Under the 2007 and 2010 Plans of Action elAC, the first steps were taken to lay the technological groundwork in the education sector (eLAc2007 (2005) and elAC2010 (2008)) but it was the 2015 Plan of Action eLAC that asserted that "the policy for maximizing use of digital technologies in the context of education must be viewed as a policy of State. This policy must include advanced training for teachers in technological, cognitive and pedagogical areas, the production of digital contents and interactive applications, innovative teaching and learning methodologies and the use of cutting-edge technological resources, including the provision of broadband and other systems with the potential to transform teaching" (elAC2015, 2010, p. 13). In response, 31 of the 38 Latin American and Caribbean countries analysed in the UNESCO study (2013a) reported having adopted a formal definition (national policy, national plan, regulatory institution and others) tied to initiatives for using ICTs in education.

The elAc2015 Plan of Action (2010) proposes four goals related to education, aimed at promoting broadband connectivity and increasing computer density in schools, implementing policies to promote research and education networks, offering more training for teachers and management teams, fostering the development of interactive multimedia applications for and by students and teachers, and lastly, obtaining the support of the Latin American Network of Educational Portals (RELPE). The progress made towards these goals in Latin America and the Caribbean varies considerably, owing primarily to lack of continuity of projects, consensuses, political support, policies and resources and other factors (Rovira and Stumpo, 2013).

\section{III}

\section{The digital divide and digital inclusion}

Although the eLAC plans have brought about real progress in terms of integrating ICTs into the member countries, there are still major inequalities in ICT access, known as the "digital divide".

The concept of the digital divide first emerged in 1999 in a report by the Department of Commerce of the United States titled "Falling through the Net: Defining the Digital Divide" (NTIA, 1999). The report defined the digital divide as the gap between two groups: those who have access to a computer, the Internet, telephone service and the contents thereof and those who do not. It also discussed the effects of technologies on people's lives.

The Organization for Economic Cooperation and Development (OECD, 2001, p. 5) defines the digital divide as "the gap between individuals, households, businesses and geographic areas at different socioeconomic levels with regard both to their opportunities to access information and communication technologies (ICTS) and to their use of the Internet for a wide variety of activities."

The United Nations (2001) indicates that the existence of the digital divide can be attributed to the income gap seen in countries around the world, the reduction of which is a global objective. It also indicates that ICTs are a factor of human development and that all countries should have national policies in place to ensure that they are widely disseminated and used to optimal advantage in different areas and among various groups.

Ballestero (2002) identifies four elements related to the digital divide:

- Availability of hardware to connect to the Internet

- Possibility of access to the Internet

- Knowledge to access and navigate the Internet

- Ability to transform online information into knowledge benefiting the user

Several studies (Ballestero, 2002; Agustín and Clavero, 2010; Rovira and Stumpo, 2013) document the significant benefits that these technologies provide to those who have and know how to use them, benefits to which those who do not have or know how to use them are excluded. To address this situation, a concept has been proposed that is about more than equipment. It is called digital inclusion and it refers to a form of societal integration necessary for community growth that goes far beyond the purely quantitative and technological aspects of the concept of the digital divide (Agustín and Clavero, 2010, p. 149).

Digital inclusion has been defined as the set of public policies related to the installation, administration, expansion, creation and development of content on wired and wireless public digital networks in individual countries, regions and communities. It includes privacy 
and security guarantees exercised fairly for all and encompasses training and incentives to develop new tools (Robinson, 2005, p. 127).

In addition, a report titled "Informe sobre la implantación y el uso de las TIC en los centros docentes de educación primaria y secundaria" [Report on ICT implementation and use in primary and secondary schools] emphasizes the central role that ICTs play in the development of the economy and society. It suggests that any community that fails to work towards digital inclusion will be left out of global development (Instituto de Evaluación y Asesoramiento Educativo/Neturity/ Fundación Germán Sánchez Ruipérez, 2007).

Since the wsIs, a number of indicators have been developed to gauge the degree of digital inclusion in society, compare the different efforts made in the countries and establish actions to take in the future for better results.

\section{IV}

\section{Indicators of digital inclusion in education}

The United Nations has suggested a rethinking of education systems, considering the advantages of ICTs and their repercussions on human development (United Nations, 2001). As a first step in this task, the levels of digital inclusion in education must be determined, using indicators developed for that purpose at the global or regional level.

On the occasion of the wsIs, a set of ICT indicators were published in 2005 that were developed by members of the Partnership on Measuring ICT for Development (2010), who have reviewed and expanded the indicators in all areas. The indicators related to education are as follows:

1. Proportion of schools with a radio used for educational purposes.

2. Proportion of schools with a television used for educational purposes.

3. Proportion of schools with telephone communication facility.

4. Learners-to-computer ratio.

5. Proportion of schools with Internet access, by type of access.

6. Proportion of learners who have access to the Internet at school.

7. Proportion of learners enrolled at the post-secondary level in ICT-related fields.

8. Proportion of ICT-qualified teachers in primary and secondary schools.

9. Proportion of schools with electricity.

According to a study by the United Nations Educational, Scientific and Cultural Organization (UNESCO, 2013a), the wsis targets directly related to education are targets 2 and 7 and their indicators:

Target 2. Connect all secondary schools and primary schools with ICTs.
1. Proportion of schools with a radio used for educational purposes.

2. Proportion of schools with a television used for educational purposes.

3. Learners-to-computer ratio.

4. Proportion of schools with Internet access, by type of access.

Target 7. Adapt all primary and secondary school curricula to meet the challenges of the information society, taking into account national circumstances.

1. Proportion of ICт-qualified teachers in schools.

2. Proportion of teachers trained to teach subjects using ICT.

3. Proportion of schools with computer-assisted instruction.

4. Proportion of schools with Internet-assisted instruction.

The elAC2015 Plan sets out six indicators related to education (ECLAC, 2012a):

1. Students-to-computer ratio by educational level.

2. Proportion of school-going children and youth who have used the Internet at an educational institution.

3. Proportion of school-going children and youth who have used the Internet in educational or learning activities, by educational level.

4. Percentage of primary and secondary schoolteachers trained to teach one or several subjects using ICT resources, by educational level.

5. Percentage of grades using ICT-assisted learning (levels 1-3), by subject: mathematics, sciences, basic computer skills (computer science), languages, art.

6. Proportion of public educational content that is digitalized.

For its part, the Inter-American Development Bank (IDB) published a set of indicators for a project on ICTS 
in education (Severin, 2010). The proposal establishes two types of indicators: input and output indicators, which include measurable aspects such as infrastructure, contents, administration, policies and others.

The Organization of Ibero-American States for Education, Science and Culture (OEI) proposed four indicators to assess the degree of digital inclusion in education: availability of ICTs, organization of schools for use of ICTS, ICT training for teachers, and the presence of ICTs in teaching practices (OEI, 2011).

Although there is some overlap between the proposed indicators described in this section, given the context of this study, only the indicators for the eLAC Plan of Action are analysed.

\section{Implementation of ICTs in education}

The developed countries have led the way in implementing ICTs in education. In the case of the European Union, important advances and achievements have been made, and the most outstanding aspects are as follows (Eurydice, 2011):

- All the countries have national ICT policies that address the entire learning process.

- $\quad$ The average number of students per computer ranges from two to four.

- Public assistance is available to procure ICTs for educational purposes.

- All the countries evaluate their national ICT and education strategies.

- The majority of the European countries use ICTS in all areas of the curriculum.

- Broadband access to the Internet is nearly universal in the European Union countries.

- Schools have websites, academic monitoring systems and other tools.

The report by Eurydice (2011) identifies the following challenges:

- ICT training is an area of weakness that must be specifically addressed to achieve digital inclusion for teachers.

- The Internet is used more for recreation than education.

The report confirms that students access the Internet at home more than at school, which may primarily have to do with the low-cost, high-speed service offered in the European Union (ECLAC, 2012b).

It should be noted that the percentages of each one of the indicated aspects vary by individual member country of the European Union.

In the case of Latin America and the Caribbean, there has been significant progress in terms of integrating ICTs into primary and secondary education, thanks to the adoption of national policies and programmes. A study conducted by the UNESCO Institute of Statistics in the countries of Latin America and the Caribbean (UNESCO, 2013a) documented the following results:

\section{(a) Proportion of schools with a radio used for educational purposes}

Fourteen countries in the Caribbean radio use for educational purposes, though at varying rates (e.g. 100\% in primary and secondary schools in the Bahamas, but $38 \%$ in primary schools and $80 \%$ in secondary schools in Dominica).

(b) Proportion of schools with a television used for educational purposes

Twenty-two countries report television-assisted learning, with the Caribbean countries reporting the highest rate of use of this technology. Of the Latin American countries, Brazil and Mexico report the greatest use.

The countries indicated in the report have invested heavily to establish radio and/or television stations for educational purposes.

\section{(c) Learners-to-computer ratio}

There are major differences between the Latin American countries and the Caribbean countries. For example, there is one computer per student in Uruguay, in contrast with other countries, such as the Dominican Republic, where there is one computer for every 122 students. Excluding extreme cases, the learner-tocomputer ratio is 27 at the primary level and 17 at the secondary level.

Of the 28 countries covered by the study, all have computer labs at both the primary and secondary levels. The study indicates that computer labs help reduce the gap in access to ICTs. 
(d) Proportion of schools with Internet access, by type of access

In 15 Caribbean countries, all secondary schools have Internet access. However, rates of access by broadband connection vary.

The Latin American countries reports high rates of Internet access, though not all have universal access. The gap in access is greater when considering schools with broadband Internet access.

In the case of Uruguay, $95 \%$ of primary schools and $100 \%$ of secondary schools have broadband access.

The data show that secondary schools tend to have greater Internet access, including broadband access, than primary schools.

(e) Proportion of ict-qualified teachers in primary and secondary schools

According to the report, only 14 countries report data on teacher training. Fewer than $10 \%$ of primary and secondary schoolteachers are qualified to use ICTS in education. There are major discrepancies between countries, with Argentina, for example, reporting 3\% of teachers as ICT-qualified, and Aruba reporting 100\%.

\section{(f) Proportion of schools with electricity}

According to the study, all primary and secondary schools in the Caribbean countries, with the exception of the Dominican Republic, have electricity.

In Uruguay, $96 \%$ of primary schools and $100 \%$ of secondary schools have electricity.

There are significant differences between the South American countries and the Central American countries. Less than $80 \%$ of primary schools in the Bolivarian Republic of Venezuela, Ecuador, Guyana and Panama have electricity.

The study points out that secondary schools are more likely to have electricity.

The indicators presented, for European and Latin American countries alike, reveal significant differences in ICT access and equipment in education, but both studies agree on the need to train teachers on the didactic use of technologies in order to successfully incorporate these into the learning and teaching process.

\section{VI}

\section{Digital inclusion in the Plurinational State of Bolivia}

Like all member countries of ECLAC, the Plurinational State of Bolivia has been taking important steps to achieve digital inclusion and promote the information society. A clear example of this was the creation in 2002 of the Agency for the Development of the Information Society in Bolivia (ADSIB), which is tasked with reducing the digital divide.

In early 2004, the Bolivian Strategy of Information and Communications Technologies for Development (ETIC) was created. In 2007, the National Digital Inclusion Plan was established to develop the knowledge society in the Plurinational State of Bolivia. Then, in the period 2012-2014, the Bolivian Digital Agenda was established for the implementation of an ICT development strategy (Rovira and Stumpo, 2013).

Major strides were made in the area of education in 2005 with the introduction of the National Policy on New Information and Communications Technologies for Education. One year later, the National ICT Programme was established, with the objective of providing adequate ICT access and use for the entire national education system and the public in general through the installation of Community Education Telecentres and the dissemination of the Educational Portal, with suitable content tailored to the national context, thus promoting broad citizen participation (Ministry of Education, 2006).

Alongside the establishment of ICT policies, efforts have been made to democratize access to electricity, a crucial indicator for digital inclusion and the development of the information society. According to the Ministry of Hydrocarbons and Energy (2010), access to electricity stands at $90.4 \%$ in cities and $50.8 \%$ in the countryside, with universal access projected for cities by 2015 and for the countryside by 2025 . The expansion in electricity coverage, along with mobile technologies, is giving more and more Bolivians access to ICTs and related services (see table 1). 
TABLE 1

ICT indicators in the Plurinational State of Bolivia, 2012-2013

\begin{tabular}{lr}
\hline Service & Units \\
\hline Internet connections & 2000000 \\
Facebook users & 2002000 \\
Mobile telephones & 9306800 \\
Smartphones & 527185 \\
Households with fixed or wireless telephones & 2013623 \\
Households with radios & 2101942 \\
Households with televisions & 1891270 \\
Computers in households & 657050 \\
\hline
\end{tabular}

Source: prepared by the authors, on the basis of data from National Statistics Institute, Bolivia. Características de la población y vivienda. Censo Nacional de Población y Vivienda 2012, 2012 [online] http://www.ine.gob.bo:8081/censo2012/ PDF/resultadosCPV2012.pdf; and M. Campos, "Santa Cruz, líder en usuarios de internet y redes sociales", El Día, 2013 [online] http://eldia.com.bo/index.php?cat $=357 \&$ pla $=3 \& i d \_$articulo $=120867$.

Note: population in the Plurinational State of Bolivia: 10,027,254. Number of households: 2,812,715.

According to data presented by the Regional Broadband Observatory at the Economic Commission for Latin America and the Caribbean, the rate of Internet penetration in the Plurinational State of Bolivia is $30 \%$ of the population. The cost of a fixed broadband connection is equivalent to $31.42 \%$ of per capita income and the cost of mobile broadband is $11.28 \%$. According to the same report, Internet upload and download speeds are the lowest in South America (ECLAC, 2012b). In response to this situation, the Bolivian government has launched the Túpac Katari satellite to improve access to and reduce the costs associated with Internet, telephone and television service (ABI, 2013).

The 2010 Avelino Siñani-Elizario Pérez Education Law establishes as its objectives to develop scientific, technical, technological and productive training in line with advances in universal technology and science throughout the Education System, as well as to promote scientific, technical, technological and pedagogical research throughout the Plurinational Education System (Ministry of Education, 2010, pp. 9 and 12). In this framework, several projects and programmes are being pursued, including "One Computer per Teacher", "Community Education Telecentres", the "National Educational Portal", "One Computer per Student", as well as educational material for radio and television and other initiatives (see table 2), designed to integrate ICTs at all levels of education (Crespo and Medinaceli, 2013).

TABLE 2

Digital inclusion in Bolivian education, 2011-2013

\begin{tabular}{lr}
\hline Indicator & Units \\
\hline Laptop computers distributed to teachers & 132693 \\
Community education telecentres installed & 340 \\
Computers in educational facilities & 10000 \\
Teachers trained by state programmes & 15000 \\
Student-to-computer ratio & $55^{\mathrm{a}}$
\end{tabular}

Source: prepared by the authors, on the basis of Ministry of Education, "Una computadora por docente", 2011 [online] http:// computadora.educabolivia.bo/; and United Nations Educational, Scientific and Cultural Organization (UNESCO), "Uso de las TIC en la Educacion en América Latina y el Caribe. Análisis regional de la integración de las TIC en la educación y de la aptitud digital (e-readiness)", Quebec, 2013 [online] http://www.uis.unesco.org/ Communication/Documents/ict-regional-survey-lac-2012-sp.pdf.

a United Nations Educational, Scientific and Cultural Organization (UNESCO, 2013a).

The project "One Computer per Teacher" is one of the most important actions for the digital inclusion of Bolivian teachers. Its objective is to give teachers access to ICTs so they can develop educational plans using these tools and the content installed on computers (Ministry of Education, 2011). This project includes technical training in the use of equipment and pedagogical training for work in the classroom.

In addition to government initiatives, actions for digital inclusion in education are being pursued by international cooperation agencies and local and foreign nongovernmental organizations (Red TICBolivia, Ayni Bolivia, Educatic and others) to offer ICT training, content development, dissemination of information and equipment and other opportunities.

ICTS are becoming more integrated into Bolivian education with every passing day, which makes it vitally important to have publications or reports on results to help quantify progress and evaluate digital inclusion in education.

In the case of the department of Tarija, no prior studies have been conducted on this topic, although investments in ICTs have been made on an ongoing basis by both the national and regional governments. 


\section{VII}

\section{Research context}

The department of Tarija, located in the southern part of the Plurinational State of Bolivia, has six provinces (Cercado, Aniceto Arce, Burdet O'Connor, Gran Chaco, Eustaquio Méndez and José María Avilés). It is home to 482,196 people, of whom approximately $40 \%$ live in the province of Cercado, where Tarija is the capital city (INE, 2012). The entire province constitutes the Tarija School District, which is where this study has been conducted.

In 2013, $42 \%$ of the department's student population between the ages of 5 and 19 (53,829 students) were enrolled in the Tarija School District, according to data provided by the Department of Education for the
Department of Tarija, which is the public institution responsible for education in the department.

According to the District Department of Education, which is the public institution responsible for education in the District of Tarija, there were 2,700 teachers employed and 20,043 students enrolled at the secondary level in the public school system in 2013. Of the 197 schools, 64 offered public secondary education and were located in urban and rural areas of the province of Cercado. Of the district's student population, $40 \%$ were enrolled in secondary school and were soon to become members of the region's labour force, which is why the study's analytical focus is on this level of education.

\section{VIII}

\section{Research methodology}

The objective of this study is to analyse digital inclusion in Bolivian public secondary education in the Tarija School District, using the ICT indicators established in the elAC Plan of Action. The study incorporates three additional indicators related to the basic conditions of electricity, radio and television as educational resources.

This is an exploratory and descriptive study based on closed surveys administered to schoolteachers, students and principals.

The surveys were based on others that were prepared in the fields of education and ICTs, such as: Profesión y Docencia (Profession and Teaching) (Gallego, 2009); Informe de las Tecnologías de la Información y de la Comunicación en la Educación (Report on Information and Communications Technologies in Education) (Instituto de Evaluación y Asesoramiento Educativo/ Neturity/ Fundación Germán Sánchez Ruipérez, 2007); and Proyecto Universidad y Sociedad del Conocimiento: ¿Es el e-learning la única respuesta? (Knowledge Society and University Project: Is e-learning the only way?) (Gewerc, 2007), which was administered at two Bolivian universities. The surveys have been validated by professionals working in the fields of ICTS and education in the Plurinational State of Bolivia and Spain.

The data were collected in the 2012 and 2013 academic years by administering surveys in paper form, due to connectivity limitations. The data collection process was supported by the education departments in Tarija district, the department and the municipal autonomous government.

The selected educational institutions were all secondary schools. Each received a number and was randomly selected. Random sampling was also used to administer the surveys in each school. 


\section{IX}

\section{Sample characteristics}

The sample consists of 311 students between the ages of 13 and 18 , of whom $52 \%$ are female and $48 \%$ are male. Of these students, $67 \%$ live in urban areas and $33 \%$ live in rural areas.

Of the 108 teachers, $51 \%$ are men and $49 \%$ are women, with the largest concentrations of female teachers in two age groups: 25 to 30 years $(21 \%)$ and 51 to 55 years $(19 \%)$, whereas the largest concentration of male teachers is in the age group from 31 to 35 years (24\%). The survey gathered data from a wide range of teachers, from those just getting started in their careers to those with many years of experience (see figure 1).

The information provided by the 15 school principals responding to the survey revealed that $60 \%$ of the participating schools offer early childhood, primary and secondary education, while $40 \%$ provide secondary education only. According to the data, 10 schools are located in city centres and outlying areas, and 5 are located in rural areas of the Tarija School District.

FIGURE 1

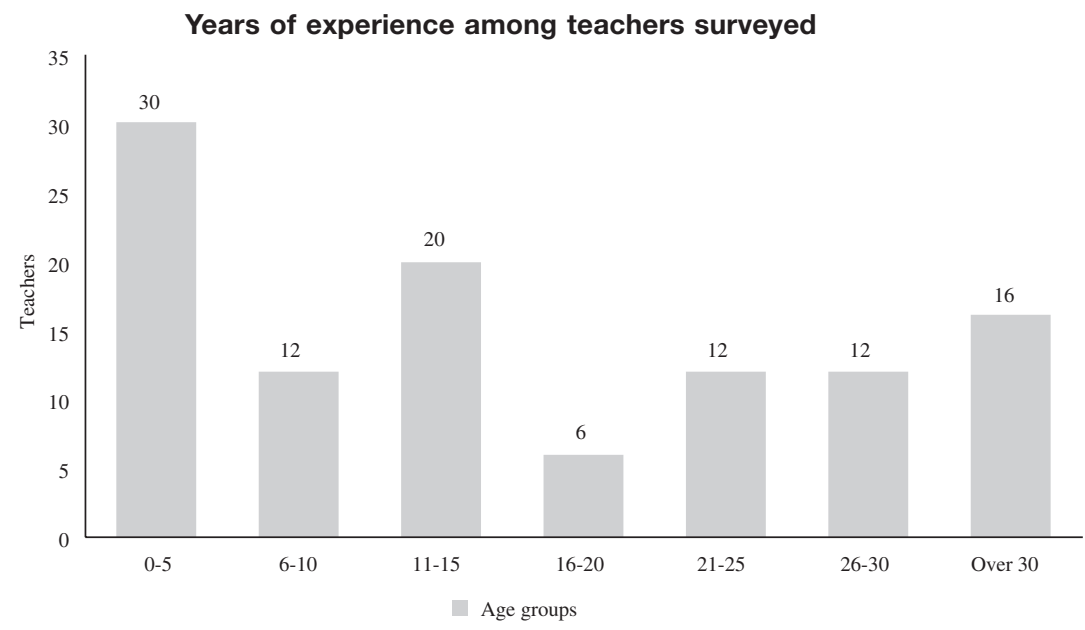

Source: prepared by the authors, on the basis of data from the survey administered to teachers as part of this study.

\section{$\mathrm{X}$}

\section{Analysis of results based on the indicators}

The analysis begins with three indicators of ICT conditions in schools (Partnership on Measuring ICT for Development, 2010). Beginning with the fourth (student/computer ratio by educational level), the indicators are those specified in the elaC Action Plan.

\section{A basic indicator: access to electricity}

According to a report by the Ministry of Hydrocarbons and Energy (2010), electricity coverage in Cercado province in the department of Tarija exceeds $80 \%$. According to data provided by the Education Department of the Municipal Autonomous Government of Tarija, 194 (98\%) schools have electricity, including 100\% of secondary schools. This is consistent with the UNESCO study (2013a), which points out that secondary schools are more likely than primary schools to have electricity.

\section{Proportion of schools with a radio used for educational purposes}

Based on information provided by the Tarija District Department of Education, $100 \%$ of educational institutions have at least one radio for educational purposes, and $20 \%$ 
of the schools surveyed have a radio in the classrooms for educational purposes.

Secondary schools have radios, but the study found that in the Plurinational State of Bolivia, educational radio stations focus exclusively on adult education (IRFA, ACLO, FIDES and others).

\section{Proportion of schools with a television used for educational purposes}

According to the Tarija District Department of Education, $52 \%$ of schools have a television used for educational purposes. Survey data reveal that $40 \%$ of schools have televisions in classrooms.

In this regard, the Bolivian government has established a strategy to develop radio and television content (Crespo and Medinaceli, 2013) and is promoting a digital television project with educational and cultural programming (El Deber, 2012). This new environment is paving the way for new opportunities to use television in the teaching and learning process in the Plurinational State of Bolivia.

\section{Students-to-computer ratio by educational level}

To offer equality of opportunity in access to computers, the Bolivian government has set itself the goal of one computer for every student, an initiative that was launched in the Tarija School District in September 2014 at the secondary level (Ministry of Education, 2014). This project will help reduce the ratio of 18 students per computer found in this study.
Of the schools surveyed, $93 \%$ have at least one computer lab containing 17 computers, on average. However, with computer lab personnel cuts, the installed infrastructure is underused, as the study found when surveying education authorities.

A comparison of these findings with the data collected in the Plurinational State of Bolivia in 2009, when there were 55 students per computer (UNESCO, 2013a), reveals significant progress towards digital inclusion.

\section{Proportion of school-going children and youth who have used the Internet at an educational institution}

According to the survey, $28 \%$ of students access the Internet at school. The study found that Internet-cafés are the space most used by students to access the Internet (46\%), as shown in figure 2.

The study findings also show that of the 74 students with a computer and Internet access at home, $28 \%$ use Internet-cafés.

In addition, the study found that $53 \%$ of school computer labs have $100 \%$ of their hardware connected to the Internet, $27 \%$ have some machines connected and the remaining $20 \%$ have no Internet connection.

In the 15 schools surveyed, ICTs are present in classrooms to varying degrees. For example, $47 \%$ have computers in the classroom, $27 \%$ have Internet connections, $20 \%$ have multimedia projectors and $13 \%$ have loudspeakers.

A full $47 \%$ of schools do not have technological equipment in the classroom. This is one of the reasons

FIGURE 2

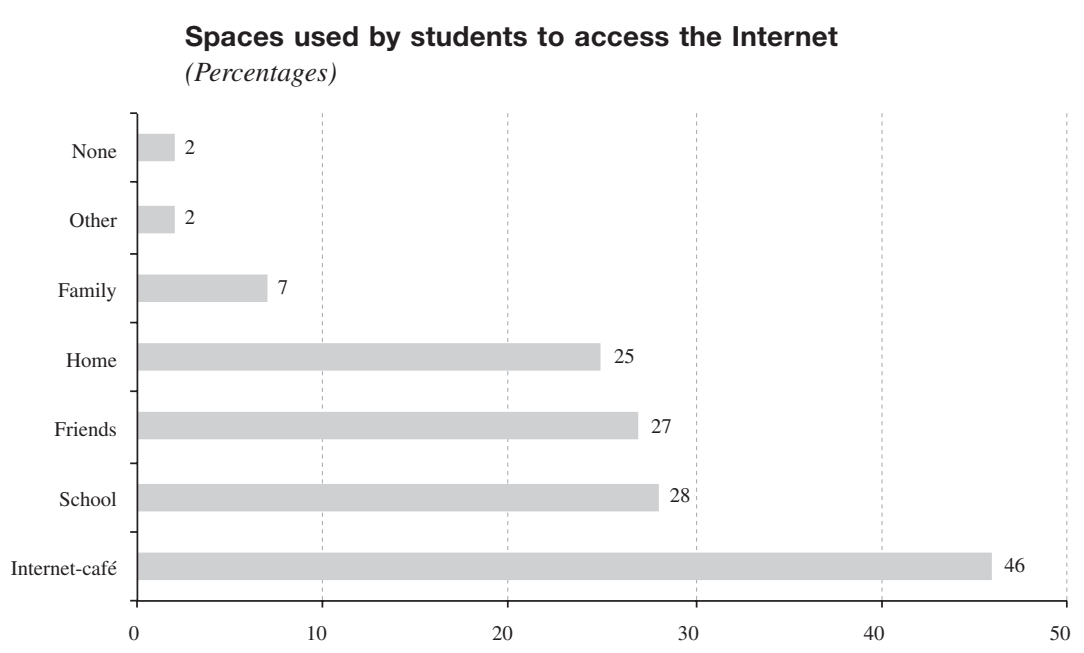

Source: prepared by the authors, on the basis of data from the survey administered to students as part of this study. 
why ICTs are not used in the teaching and learning process, as explained by the principal of the Aniceto Arce School, Sonia Lema Ruiz, to the newspaper El Nacional (Velásquez, 2013).

School limitations do not prevent students from accessing the Internet, since $93 \%$ of survey respondents report having a cellular phone, and $46 \%$ of them have connected to the Internet using the device. This information coincides with a report by the Telecommunications and Transport Oversight and Regulatory Authority (ATT) of the Plurinational State of Bolivia, which notes that everyday more Bolivians are connecting to the Internet using wireless devices (ATT, 2012). This is very relevant in the context of education, given that the spread of mobile technologies and their ease of use offer numerous possibilities for work in the classroom (UNESCO, 2013b).

According to the survey results, $44 \%$ of the students access the Internet at least twice per week and remain connected for an hour on average.

The hardware already in place in schools is a positive aspect, although there are significant challenges yet to tackle, such as the number of computers available for students, Internet access on all machines and use of ICTs in the classroom as a resource for the teaching and learning process.

\section{Proportion of school-going children and youth who have used the Internet in educational or learning activities, by educational level}

In all, $80 \%$ of the students report having at least one class per week that uses ICTs, and $43 \%$ of them attend rural schools, which suggests that teachers are interested in introducing ICTS in education.

Of the students surveyed, $87 \%$ report using the Internet for educational purposes, especially to find information. This percentage indicates the importance of the Internet as an information source for adolescents (see figure 3 ).

The findings suggest that recreational activities in cyberspace are of great importance in the lives of teenagers.

The study also shows that students have become skilled at using ICTs, especially when it comes to automated office software programmes (PowerPoint, Word and others) and Internet browsers (see figure 4).

In this new context, the challenge for teachers is to help their students cultivate these skills, both for the acquisition of specific knowledge and for lifelong learning.

By cross-referencing data, the study finds that $50 \%$ of the students who know how to use PowerPoint and Word and $47 \%$ of those who use Internet Explorer and Google Chrome do not have a computer at home.

Of the students surveyed, $65 \%$ indicate that they have a profile on Facebook, 15\% on Google Plus and $14 \%$ on Twitter. And $23 \%$ of adolescents report using more than one social network. This is a new space that teachers that could use to promote learning through collaborative group work.

The percentage of students who access Internet services is high, yet $37 \%$ of young women and $23 \%$ of young men do not have an email account. Meanwhile, $41 \%$ of female students and $45 \%$ of male students check email two or more times per week. This information

FIGURE 3

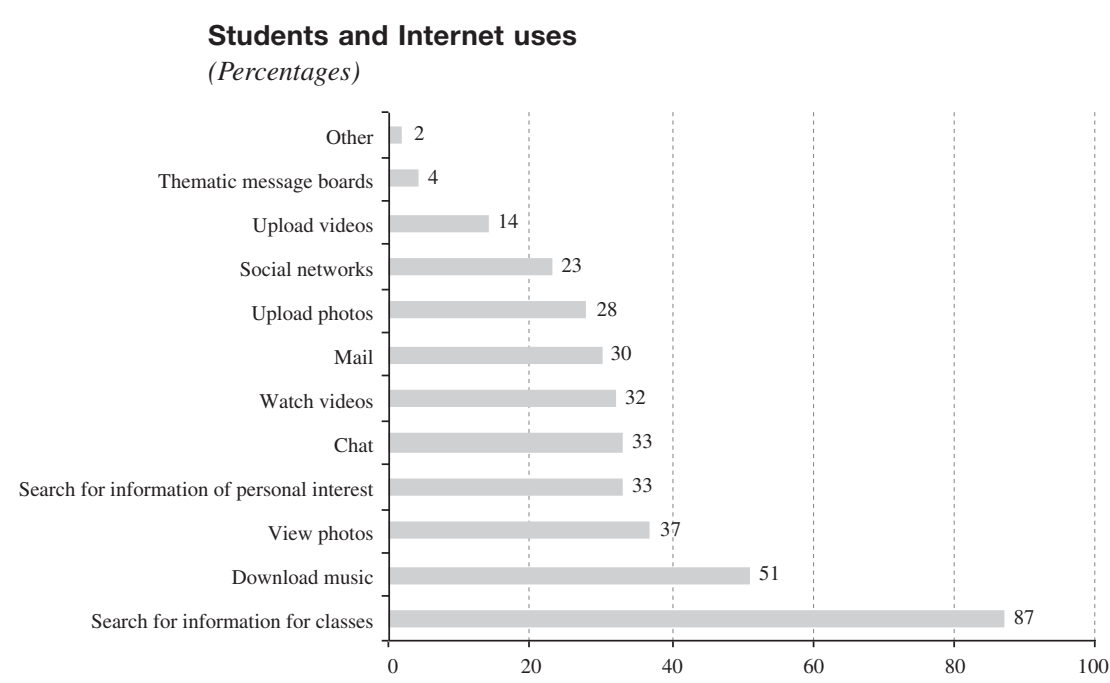

Source: prepared by the authors, on the basis of data from the survey administered to students as part of this study. 
FIGURE 4

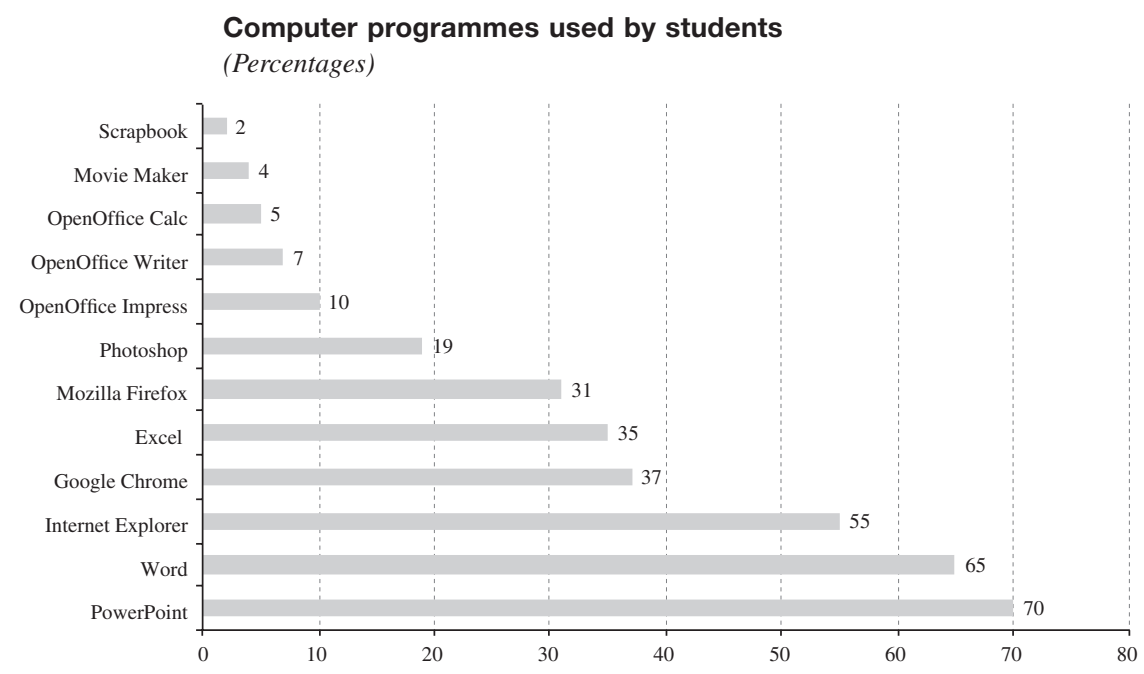

Source: prepared by the authors, on the basis of data from the survey administered to students as part of this study.

indicates that adolescents access the Internet frequently, so the task for teachers is to steer their ICT use towards educational purposes.

Of the students surveyed, 53\% report having published content on the Internet. Within that group, $23 \%$ have uploaded a video to YouTube, $17 \%$ have created an animated slideshow online, $11 \%$ have created a webpage and $9 \%$ have uploaded photos to Flickr. This findings show that young people are becoming not just consumers but creators of online content, thus the importance of programmes to prevent and control risks to youth online.

Students are looking for different ways to access technologies, especially the Internet, as a means of expression and construction of identity (Morduchowicz, 2012, p. 68). In addition, "in the world of the teenager, not being able to understand maths is oK; not being able to use a computer or not having a mobile phone is not "Cool"' (TACCLE, 2009, p. 55). In this new reality, the teacher's guidance role is crucial for channeling teenagers' enthusiasm for ICTs towards learning.

\section{Percentage of primary and secondary schoolteachers trained to teach one or several subjects using ICT resources, by educational level}

The participating teachers, male and female alike, report having acquired ICT skills through individual tutoring or paid classes and by teaching themselves (self-study). The percentage of male teachers trained in ICTS is greater than the percentage of female teachers (see figure 5).
The findings point up the need to continue working on training programmes, in order to reduce gender gaps and ensure digital inclusion for the entire teaching corps.

The surveyed teachers prefer classroom training (44\%) and mixed training (classroom and virtual, 43\%) to completely virtual training (12\%).

One of the reasons why virtual education is not an option for teachers is limited Internet access. According to the survey, $53 \%$ of female teachers and $56 \%$ of male teachers do not have Internet access at home.

In all, $58 \%$ of the teachers say they need to receive training on integrating ICTS into the curriculum and their teaching practices, as well as technical training on using computers and software programmes (see figure 6).

The results suggest the need for a comprehensive pedagogical and technological training plan to help teachers develop creativity and acquire skills in the area of ICTs.

The surveyed teachers report having skills with office automation software (44\% with spreadsheets, $53 \%$ with word processing and $28 \%$ with multimedia presentations), use of hardware $(51 \%)$ and basic operating system functions (69\%). However, they are less familiar with software for editing audio (67\%), images $(61 \%)$ and video $(68 \%)$. This is an obstacle to building interactive and contextualized content that addresses new educational needs. In response, the Ministry of Education, as part of its "One Computer per Teacher" project, will provide instruction in the development of educational resources as a component of its training plan (Ministry of Education, 2011). 
FIGURE 5

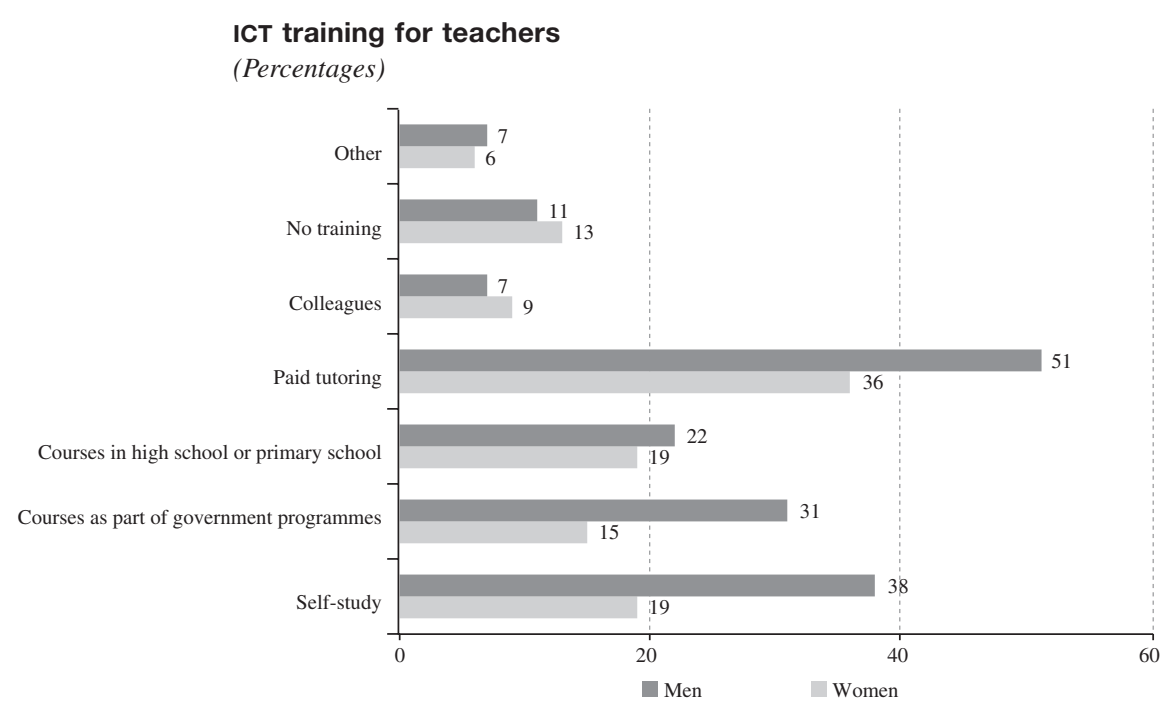

Source: prepared by the authors, on the basis of data from the survey administered to teachers as part of this study. ICT: information and communications technologies.

FIGURE 6

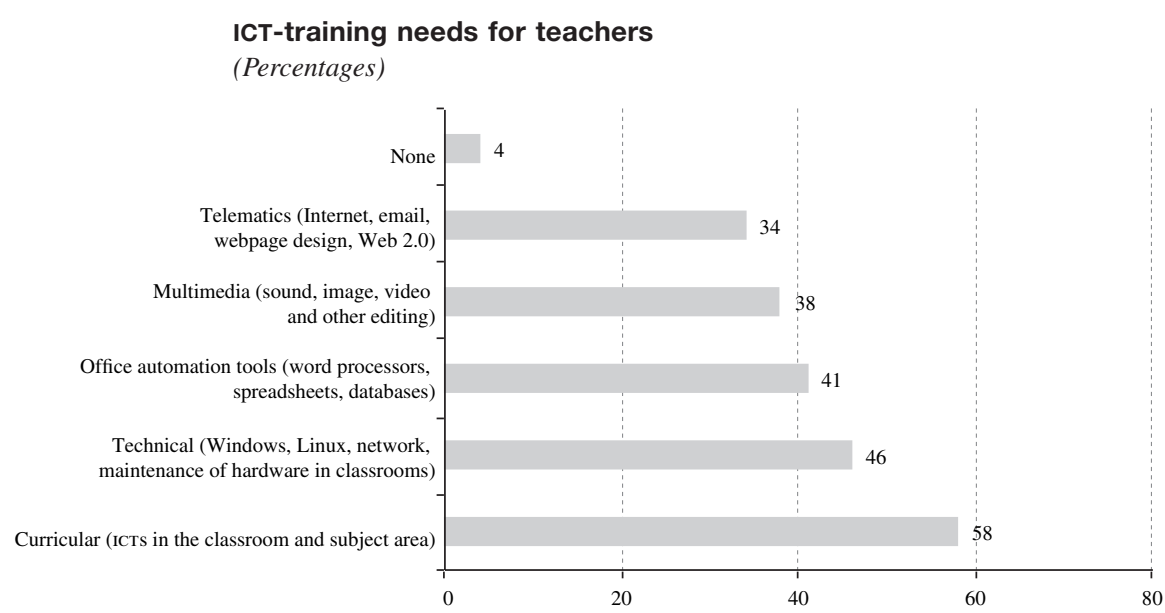

Source: prepared by the authors, on the basis of data from the survey administered to teachers as part of this study.

ICT: information and communications technologies.

Office automation tools: set of software programmes to facilitate office work.

With respect to Internet resources, a high percentage of teachers report using email (80\%), chat services (63\%), Internet browsers $(60 \%)$ and search engines $(74 \%)$. However, they are unfamiliar with but would like to learn how to use blogs (87\%), wikis (92\%), message boards (79\%), online videos (72\%), educational platforms (85\%), social networks $(68 \%)$, videoconferencing $(85 \%)$ and other online resources. These results reveal that teachers are unfamiliar with the diverse educational possibilities offered by cyberspace.
A full $63 \%$ of the teachers report using the Internet to prepare their lessons, which demonstrates the importance of online content as an information source for teachers.

The findings show that teachers prepare diverse resources for their classes, based especially on office automation software, yet $22 \%$ of them say they do not prepare any resources using computer-based tools (see figure 7).

According to data obtained from the Tarija District Department of Education, the training currently provided 
to teachers is focused on how to use a computer, but the challenge is to provide training in ICT use to improve the teaching and learning process, which includes the creation of digital resources.

\section{Proportion of public educational content that is digitalized}

According to information provided by the Department of Education of the Municipal Autonomous Government of Tarija, the Tarija School District does not have a portal of regional resources, though there is a project underway to develop one.

At the national level, the Ministry of Education has created the Educabolivia portal as a project within the National Programme for New Information and
Communications Technologies for Education, for stakeholders in the educational process: parents, teachers and students. The portal provides elements to complement education and community development by offering quality educational experiences, services, resources and information that meet the needs and interests of the educational community (Educabolivia, 2013).

The portal has four sections: Teachers, Community, Students and Resources. The first three sections provide access to current information for the respective target group. The last section is intended to provide access to educational resources (see table 3 ).

The Educabolivia portal, created in 2007, represents a major step forward, especially in terms of introducing resources that are in line with the education law and the local context.

FIGURE 7

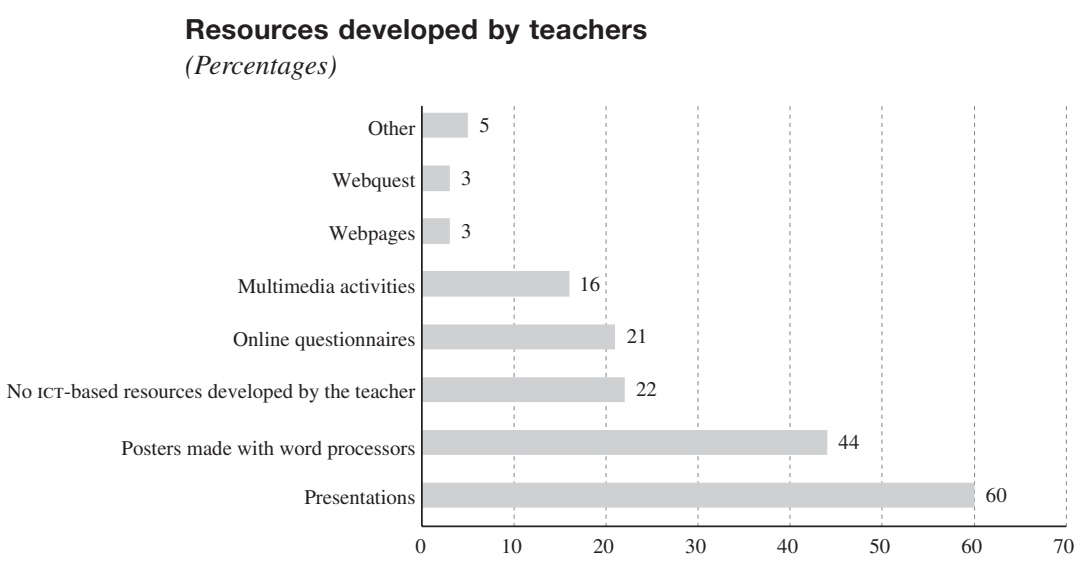

Source: prepared by the authors, on the basis of data from the survey administered to teachers as part of this study.

TABLE 3

Resources on the Educabolivia portal

\begin{tabular}{lll}
\hline Section of the portal & Content & Number and type of resources \\
\hline Educational websites & Link from the portal to external education-related websites. & 1061 links to websites \\
\hline Plans & Gives teachers guidelines for planning lessons with educational content. & 329 lesson plans \\
\hline Texts & Provides access to abstracts on the listed titles and enables downloads. & 347 titles \\
\hline Games & $\begin{array}{l}\text { There is a series of educational games created by nongovernmental organizations } 15 \text { educational games for the } \\
\text { with offices in the Plurinational State of Bolivia. The games are classified by } \\
\text { subject area. }\end{array}$ & $\begin{array}{l}\text { preschool level, } 32 \text { for the primary } \\
\text { level and 23 for secondary level }\end{array}$ \\
\hline Libraries & List of virtual libraries that can accessed free of charge. & 11 links \\
\hline Audio & Space to facilitate access to audio books that can be downloaded from the portal. 11 audio books \\
\hline Presentations & $\begin{array}{l}\text { Space that contains PowerPoint presentations on different subjects, by } \\
\text { educational level. }\end{array}$ & 15 presentations \\
\hline Software & $\begin{array}{l}\text { Enables downloads of different educational software programmes, which are } \\
\text { accompanied by a short description and an indication of the suggested level. }\end{array}$ & \\
\hline Images & A bank of images accompanied by short descriptions. & 495 images \\
\hline Videos & Provides educational videos/cartoons. & 24 videos/cartoons \\
\hline
\end{tabular}

Source: prepared by the authors, on the basis of information from Educabolivia, 2013 [online] http://www.educabolivia.bo/. 


\section{XI}

\section{Analysis of results vis-à-vis other studies}

As this study was being conducted, Terrazas and Ibarra (2013) conducted their own on ICTs and education in the department of La Paz in the Plurinational State of Bolivia with a sample of 100 secondary school students. This study has made it possible to analyse aspects in common (see table 4).

According to the study by Terrazas and Ibarra (2013), the students in La Paz use ICTs to build social relationships but use them very infrequently to search for information on the Internet.

As for the teachers, the researchers indicate that the computers donated under the project "One Computer per Teacher" are being underused due to the generational digital divide between students and teachers, lack of training in their use and teachers' reticence to use new technologies, which is consistent with the findings of this study.

The trend of the results of the work by Terrazas and Ibarra (2013) generally coincides with a number of aspects in this study.

A study conducted by the Centre for Studies into Economic and Social Reality (CERES), the organization Ciudadanía and the newspaper Los Tiempos in the department of Cochabamba (CERES/Ciudadanía/Los Tiempos, 2013) found that the population, in general, uses the Internet to: study or learn (38\%), work (36\%), participate in social networks (23\%) and communicate with family and friends (21\%).

The cited study shows that young people between the ages of 18 and 25 use the Internet to study and learn. This data point reveals a trend in Internet use that is consistent with the finding by the present study that teenagers use the Internet to search for information for their classes.

Similar studies have been carried out throughout Latin America, such as the one conducted in Peru by Balarin (2013), which indicates that the country's schools have low rates of Internet access (17.4\% in primary schools and $36.7 \%$ in secondary schools). The studentto-computer ratio is 5 at the primary level and 9 at the secondary level, due primarily to the One Laptop Per
Child (OLPC) programme under the model "one child, one computer", as well as the installation of technology resource centres in schools. In addition to the delivery of computers, 12,860 televisions and 80,000 robotics kits have been distributed to primary and secondary schools. Since 2008, Peruvian schools have a television channel and an educational portal with a variety of digital resources. Moreover, $67.9 \%$ of primary schoolteachers and $70.7 \%$ of secondary schoolteachers have received training in using a computer.

According to the cited study, Peruvian teenagers have developed ICT-related skills (office automation software, search engines and computers), which will help ensure their digital inclusion. However, Internet access at school and training for teachers on how to use ICTS in the classroom continue to be major challenges (Balarin, 2013).

Another study, conducted in Buenos Aires (Lago, 2012), highlights the important progress that has been made in digital inclusion in education, mainly due to local and national projects, such as the Conectar Igualdad [Connect Equality] project launched in 2010, which distributed one computer to every student and every teacher in the public school system. This initiative has been accompanied by a large investment in the installation of the technologies needed for schools to connect to the Internet.

The Lago study (2012) has identified teacher training, Internet connection, broadband and technical difficulties as some of the challenges involved in bringing ICTS to the classroom. It also discovered that students tend to use computers for entertainment purposes (games, videos, music and other forms of entertainment). According to the study, computers are having a very strong impact on households, inasmuch as they are drawing the students' families closer to the digital world, a major step forward for the Information Society.

The cited international studies coincide with this study in their identification of teacher training, hardware and broadband connectivity as some of the priorities for digital inclusion in education. 
TABLE 4

Comparison of studies conducted in La Paz and Tarija, 2012-2013

\begin{tabular}{|c|c|}
\hline Students in La Paz & Students in Tarija \\
\hline $\begin{array}{l}\text { For the most part, the students access the Internet at } \\
\text { Internet-cafés. }\end{array}$ & $46 \%$ of the students access the Internet at Internet-cafés. \\
\hline Students report accessing the Internet from their cell phones. & $\begin{array}{l}46 \% \text { of the students surveyed in Tarija report having accessed } \\
\text { the Internet using their telephone. }\end{array}$ \\
\hline $\begin{array}{l}\text { The percentage of students who access the Internet at home } \\
\text { is } 1 \% \text {. }\end{array}$ & $\begin{array}{l}25 \% \text { of the students indicate that they access the Internet at } \\
\text { home. }\end{array}$ \\
\hline The majority do not have a computer or Internet at home. & $51 \%$ of the students do not have a computer at home. \\
\hline $\begin{array}{l}\text { The teenagers do not have access to a telecentre or to } \\
\text { computer labs at school because infrastructure is inadequate. }\end{array}$ & $\begin{array}{l}28 \% \text { of the students use computer labs at school to access a } \\
\text { computer and the Internet. }\end{array}$ \\
\hline $\begin{array}{l}\text { The students report having practiced with office automation } \\
\text { software. }\end{array}$ & $\begin{array}{l}\text { The students use various office automation software } \\
\text { programmes: PowerPoint }(70 \%) \text {, Word }(65 \%) \text {, Excel }(35 \%) \text {. }\end{array}$ \\
\hline They use social networks like Facebook. & $\begin{array}{l}43 \% \text { of the student surveyed have a profile on Facebook. In } \\
\text { addition, they have accounts on more than one social network. }\end{array}$ \\
\hline $\begin{array}{l}54 \% \text { of survey respondents state that the focus of their Internet } \\
\text { use is on improving searches for information and research. }\end{array}$ & $\begin{array}{l}87 \% \text { of the students report using the Internet to search for } \\
\text { information for their classes. }\end{array}$ \\
\hline $\begin{array}{l}16 \% \text { do not identify the specific use of ICTS in their } \\
\text { educational activities. }\end{array}$ & $\begin{array}{l}30 \% \text { of the students report having at least one class per week } \\
\text { with ICTs. }\end{array}$ \\
\hline
\end{tabular}

Source: prepared by the authors, on the basis of L. Terrazas and J. Ibarra, Estrategia de integración de las TIC en el sistema de educación en los municipios de La Paz y El Alto, 2013 [online] http://www.pieb.com.bo/sipieb_notas.php?idn=8169.

\section{XII}

\section{Conclusions}

The study produced the following conclusions:

- The indicators used, as well as the local and international studies analysed, clearly demonstrate the education system in the Plurinational State of Bolivia, and especially in Tarija, is advancing towards digital inclusion.

- The study has verified the existence, but not the use, of ICTs in the teaching and learning process at the secondary level.

- All secondary schools have access to electricity, a key condition of digital inclusion.

- The existence of televisions in schools is positive, though it does not guarantee connectivity to the digital television station that carries the educational channel.

- In the case of radio, educational programming for adults has been offered; however, there are no specific projects at the secondary level, although a high percentage of schools have a radio.

- The One Computer Per Student project is having a direct effect on the student-to-computer ratio and reducing the digital divide at the secondary level in the Tarija School District.
- In response to the country's low rate of broadband Internet connectivity (ECLAC, 2012b) and the still-high student-to-computer ratio, students look for alternate ways of getting online, such as at Internet-cafés.

- With the rapid expansion of mobile technologies in the Plurinational State of Bolivia, large numbers of students are now able to access these technologies, creating a new space with numerous possibilities for education (UNESCO, 2013b).

- The students have acquired skills in using a computer and various software programmes, a finding corroborated by the research cited in the study.

- Students tend to use the Internet for information searches and entertainment.

- Students connect to the Internet at least two times per week.

- Training for teachers is largely a product of their own enthusiasm and personal effort, but gender gaps have been identified in terms of the type of training received.

- The integration of ICTs into educational curricula is one of the top priorities identified by teachers, a 
reminder that the challenge of incorporating ICTS in education is not necessarily related to hardware, but rather to training for teachers on the didactic, pedagogical and creative use of ICTs in order to improve the teaching and learning process (Crespo and Medinaceli, 2013).

- Schools are contributing to digital inclusion, and to the extent that they extend their hours and improve technological and connectivity conditions, they will contribute to equality of opportunities for youth in the Information and Knowledge Society.
- Existing technological conditions and government projects are fostering digital inclusion in the Tarija School District, but this is a process that requires heavy investment over time to maintain, upgrade and expand the technological infrastructure, as well as ongoing training for stakeholders in the educational process.

- This study constitutes an important quantitative and descriptive input that could be complemented by open-ended questions to survey the participants on their perceptions, which would lay the groundwork for a broader quantitative-qualitative analysis of ICTs in education.
ABI (Agencia Boliviana de Información) (2013) [online] http:// www3.abi.bo/\#.

$\operatorname{ACLO}(\mathrm{n} / \mathrm{d})$ [online] http://aclo.org.bo/bolivia/.

Agustín, M.C. and M. Clavero (2010), "Indicadores sociales de inclusión digital: Brecha y participación ciudadana", Derecho, gobernanza y tecnologías de la información en la sociedad del conocimiento, F. Galindo-Ayuda and A. Rover (eds.), Zaragoza, Prensas Universitarias de Zaragoza [online] http:// eprints. rclis.org/14264/.

ATT (2012) [online] http://att.gob.bo/index.php/component/content/ category/124-sisatt.

Ayni Bolivia [online] http://www.redayni.org/.

Balarin, M. (2013), "Programa TIC y educación básica. Las políticas TIC en los sistemas educativos de América Latina. Caso Perú" [online] http://www.unicef.org/argentina/spanish/Peru_ok.pdf.

Ballestero, F. (2002), La brecha digital. El riesgo de la exclusión en la sociedad de la información, Madrid, Fundación Retevisión.

Campos, M. (2013), "Santa Cruz, líder en usuarios de internet y redes sociales", El Día [online] http://eldia.com.bo/index. php?cat $=357 \&$ pla $=3 \&$ id_articulo $=120867$.

CERES (Centre for Studies into Economic and Social Reality)/ Ciudadanía/Los Tiempos (2013), "Cochabambinos usan Internet principalmente para estudiar o aprender y luego para trabajar" [online] http://www.ceresbolivia.org/ archivos/745.

Crespo, A. and K.I. Medinaceli (2013), "Políticas en tecnologías de la información y comunicación en el nuevo contexto social y educativo en Bolivia", Revista OIDLES, vol. 7, No. 14 [online] http://www.eumed.net/rev/oidles/14/educacion-bolivia.html.

ECLAC (Economic Commission for Latin America and the Caribbean) (2012a), "Lista de indicadores para el elac2015", Project Document, Santiago, Chile [online] http://www.iadb.org/ intal/ intalcdi/PE/2012/10486.pdf.

(2012b), Estado de la banda ancha en América Latina y el Caribe, 2012. Informe del Observatorio Regional de Banda Ancha (ORBA), Santiago, Chile [online] http://www. eclac.org/ publicaciones/xml/9/48449/EstadobandaAnchaenAMLC.pdf.

Educabolivia (2013) [online] http://www.educabolivia.bo/.

Educatic (n/f) [online] http://www.educatic.org.bo/.

elAC (2010), Plan of Action for the Information and Knowledge Society in Latin America and the Caribbean (eLAC 2015), Lima [online] http://www.cepal.org/cgi-bin/getProd.asp?xml=/ socinfo/noticias/documentosdetrabajo/5/41775/P41775. xml\&xsl=/socinfo/tpl-i/p38f.xsl\&base=/elac2015/tpl-i/ top-bottom.xsl.

elac2010 (2008), Plan de Acción Regional sobre la Sociedad de la Información en América Latina y el Caribe (eLAC2010), El Salvador [online] http://www.eclac.org/cgi-bin/getprod. asp? xml=/elac2015/noticias/paginas/9/44099/P44099. xm1\&xsl=/elac2015/tpl/p18f.xs1\&base=/elac2015/tpl/topbottom.xsl.

elac2007 (2005), Plan of Action for the Information Society in Latin America and the Caribbean eLAC 2007, Rio de Janeiro [online] http://www.cepal.org/socinfo/noticias/ documentosdetrabajo/5/21685/eLAC\%202007\%20English.pdf.

El Deber (2012), "Presidente lanza el canal estatal", 10 May [online] http://www.eldeber.com.bo/nota.php?id=120510222153

Eurydice (2011), Key Data on Learning and Innovation through ICT at School in Europe 2011 [online] http://eacea.ec.europa. eu/education/eurydice/documents/key_data_series/129EN.pdf.

Gallego, D. (2009), "Profesión y docencia: El nuevo perfil de la profesión docente. Informe 2007", IV Congreso Internacional de Educared "Educar en comunidad", Madrid, Fundación Telefónica.

Gewerc, A. (coord.) (2007), "Universidad y sociedad del conocimiento: ¿Es el e-learning la única respuesta?" [online] http://unisic.usc. es/informes/Informe_final_proyectoA-Definitivo.pdf.

INE (National Institute of Statistics) (2012), Bolivia. Características de la población y vivienda. Censo Nacional de Población y Vivienda 2012 [online] http://www.ine.gob.bo:8081/ censo2012/PDF/resultadosCPV2012.pdf.

Instituto de Evaluación y Asesoramiento Educativo/Neturity/ Fundación Germán Sánchez Ruipérez (2007), Las tecnologías de la información y de la comunicación en la educación. Informe sobre la implantación y el uso de las TIC en los centros docentes de educación primaria y secundaria (curso 2005- 2006), Madrid [online] http://www.oei.es/tic/TICCD.pdf.

IRFA (Instituto Radiofónico Fe y Alegría) [online] http://www. irfabolivia.org/.

Lago, S. (2012), "Inclusión digital en la educación pública argentina. El programa Conectar Igualdad", Revista Educación y Pedagogía, vol. 24, No. 64 [online] http://aprendeenlinea.udea.edu.co/ revistas/index.php/revistaeyp/article/viewFile/14204/12547.

Ministry of Education (2014), "Gobierno inició la entrega de computadoras quipus a estudiantes de primero a sexto secundaria de Tarija" [online] http://www.minedu.gob.bo/ index.php/component/k2/3-noticias-recientes/3056-gobiernoinicio-la-entrega-de-computadoras-quipus-a-estudiantes-desecundaria-en-tarija.

(2011), "Una computadora por docente" [online] http:// computadora.educabolivia.bo/.

(2010), "Ley de la Educación "Avelino Siñani-Elizario Pérez"” [online] http://www.oei.es/quipu/bolivia/Leydla\%20.pdf. (2006), "Programa Nacional TICS. Tecnologías de información y comunicación para el fortalecimiento del sistema 
educativo y el desarrollo comunitario" [online] http://www. gesci. org/old/files/docman/About_Programa_Nacional_de_TICS.pdf. Ministry of Hydrocarbons and Energy (2010), "Plan de Universalización Bolivia con Energía 2010-2015" [online] http://www2.hidrocarburos.gob.bo/phocadownload/PLAN\%20 DE\%20UNIVERSALIZACI\%C3\%93N\%20BOLIVIA\%20 CON\%20ENERG\%C3\%8DA.pdf.

Morduchowicz, R. (2012), Los adolescentes y las redes sociales, Madrid, Fondo de Cultura Económica.

NTIA (National Telecommunications and Information Administration) (1999), "Falling Through the Net: Defining the Digital Divide" [online] http://www.ntia.doc.gov/legacy/ntiahome/fttn99/ contents.html.

OECD (Organization for Economic Cooperation and Development) (2001), Understanding the Digital Divide, Paris [online] http:// www.oecd.org/sti/ieconomy/1888451.pdf.

OEI (Organization of Ibero-American States for Education, Science and Culture) (2011), La integración de las TIC en la escuela. Indicadores cuantitativos y metodología de la investigación [online] http://www.oei.es/idie/IntegracionTIC.pdf.

Partnership on Measuring ICT for Development (2010), "Indicadores clave sobre tic" [online] http://www.itu.int/ dms_pub/itu-d/opb/ ind/D-IND-ICT_CORE-2010-PDF-S.pdf.

Red TicBolivia [online] http://www.ticbolivia.net/.

Robinson, S.S. (2005), "Reflexiones sobre la inclusión digital", Nueva Sociedad, No. 195 [online] http://www.nuso.org/upload/ articulos/3244_1.pdf.

Rovira, S. and G. Stumpo (comp.) (2013), Entre mitos y realidades. TIC, políticas públicas y desarrollo productivo en América Latina (LC/L.3600), Santiago, Chile, Economic Commission for Latin America and the Caribbean [online] http://www.iadb. org/intal/intalcdi/PE/2013/10767.pdf.
Severin, E. (2010), "Tecnologías de la información y la comunicación (TICs) en educación. Marco conceptual de indicadores", Technical Notes, No. 6 [online] http://idbdocs.iadb.org/wsdocs/ getdocument.aspx?docnum $=35128349$.

TACCLE (Teachers' Aids on Creating Content for Learning Environments) (2009) [online] http://www. taccle.eu/index2.php?option=com docman\&task $=$ doc_view\&gid $=16 \&$ Itemid $=46$.

Terrazas, L. and J. Ibarra (2013), Estrategia de integración de las TIC en el sistema de educación en los municipios de La Paz y El Alto [online] http://www.pieb.com.bo/sipieb_notas. php?idn $=8169$.

UNESCO (United Nations Educational, Scientific and Cultural Organization) (2013a), "Uso de las TIC en la educación en América Latina y el Caribe. Análisis regional de la integración de las tic en la educación y de la aptitud digital (e-readiness)", Quebec [online] http://www.uis. unesco.org/Communication/ Documents/ict-regional-survey-lac-2012-sp.pdf.

(2013b), UNESCO Policy Guidelines for Mobile Learning, Paris [online] http://unesdoc.unesco.org/images/0021/002196/ 219641E.pdf.

United Nations (2001), Informe sobre desarrollo humano 2011. Poner el adelanto tecnológico al servicio del desarrollo humano, Madrid, Mundi-Prensa Libros S.A. [online] http:// hdr.undp. org/sites/default/files/hdr_2001_es.pdf.

Velásquez, V. (2013), "Las computadoras donadas a los maestros no son empleadas en el aula", El Nacional, 2 July [online] http:// www.elnacionaltarija.com/?p=33769.

wsIs (World Summit on the Information Society) (2005), "Tunis Commitment" [online] http://www.itu.int/wsis/docs2/tunis/ off/7.html.

(2003), "Declaration of Principles" [online] http://www.itu. int/wsis/docs/geneva/official/dop.html. 